\section{Evaluating Cover Crop Mulches for No-till Organic Production of Onions}

\author{
Emily R. Vollmer ${ }^{1,3}$ and Nancy Creamer ${ }^{2}$ \\ Department of Horticultural Science, North Carolina State University, \\ Campus Box 7609, Raleigh, NC 27695
}

\author{
Chris Reberg-Horton ${ }^{2}$ \\ Department of Crop Science, North Carolina State University, Campus Box \\ 7620, Raleigh, NC 27695
}

\author{
Greg Hoyt ${ }^{2}$ \\ Department of Soil Science, North Carolina State University, 455 Research \\ Drive, Mills River, NC 28759
}

Additional index words. Allium cepa, cowpea (Vigna unguiculata), millet (Setaria italica), nitrogen, soybean meal, weeds, conservation tillage

\begin{abstract}
Cover crops of foxtail millet 'German Strain R' [Setaria italica (L.) Beauv.] and cowpea 'Iron \& Clay' [Vigna unguiculata (L.) Walp.] were grown as monocrops (MIL, COW) and mixtures and compared with a bare ground control (BG) for weed suppression and nitrogen $(\mathrm{N})$ contribution when followed by organically managed no-till bulb onion (Allium cepa L.) production. Experiments in 2006-2007 and 2007-2008 were each conducted on first-year transitional land. Mixtures consisted of cowpea with high, middle, and low seeding rates of millet (MIX-70, MIX-50, MIX-30). During onion production, each cover crop treatment had three $N$ rate subplots $(0,105$, and $210 \mathrm{~kg} \mathrm{~N} / \mathrm{ha})$ of surface-applied soybean meal [Glycine max (L.) Merrill]. Cover crop treatments COW and BG had the greatest total marketable onion yield both years. Where supplemental baled millet was applied in 2006-2007, onion mortality was over 50\% in MIL and MIX and was attributed to the thickness of the millet mulch. Nitrogen rates of 105 and $210 \mathrm{~kg}$ $\mathrm{N} /$ ha increased soil mineral $\mathrm{N}\left(\mathrm{NO}_{3}{ }^{-}\right.$and $\left.\mathrm{NH}_{4}{ }^{+}\right)$on $\mathrm{BG}$ plots 2 weeks after surface application of soybean meal each year, but stopped having an effect on soil mineral $\mathrm{N}$ by February or March. Split applications of soybean meal could be an important improvement in $\mathbf{N}$ management to better meet increased demand for $\mathrm{N}$ uptake during bulb initiation and growth in the spring.
\end{abstract}

Conservation tillage practices promote soil quality and fertility in accordance with organic principles (Peigné et al., 2007); however, conservation tillage in organic systems is particularly challenging. Peigné et al. (2007) emphasized that success of conservation tillage in organic systems is highly influenced by management of crop rotation for weed and disease control and nitrogen availability. Cover crops used in rotation with cash crops require additional management; however, they also contribute multiple services such as nitrogen $(\mathrm{N})$ fixation and contribution to subsequent crops; weed, disease, or pest suppression; reduction of topsoil and agrochemical runoff; increase in soil organic matter; and scavenging of residual $\mathrm{N}$ after shallow-rooted crops (Cherr et al., 2006a; Lu et al., 2000). The selection of

Received for publication 23 Mar. 2009. Accepted for publication 15 Sept. 2009.

Funding was received from the Sustainable Agriculture Research and Education program and the NC Beautiful organization.

We thank Kenneth Fager for technical assistance. ${ }^{1}$ Graduate Research Assistant.

${ }^{2}$ Professor.

${ }^{3}$ To whom reprint requests should be addressed; e-mail vollmer.emily@gmail.com. cover crop species suitable for crop rotation, climate, and specific desirable services is important for integration into diverse farming systems. In the southeastern United States, heat-tolerant cover crops can be grown between spring and fall vegetable production (Creamer and Baldwin, 2000).

In conservation tillage, surface residues are generally unharvested crop remains or cover crops that were killed with herbicides or mechanical methods, the latter in an organic system (Creamer and Dabney, 2002). Frost kill of certain cover crops is an organic option that could circumvent cover crop regrowth problems because mechanical kill techniques are highly dependent on plant growth stage (Ashford and Reeves, 2003).

Use of summer cover crops for no-till fall cropping is an option in climates warm enough for a fall production season. No-till vegetable production after a summer cover crop compared with tilled bare ground resulted in higher or equivalent yield for lettuce (Wang et al., 2008) and broccoli (Abdul-Baki et al., 1997a). Wang et al. (2008) also compared organic and conventional management systems over a 5-year period and found organically grown lettuce had lower yields the first 2 years but equivalent or greater yields in the subsequent 3 years compared with conventional production.
Legume and grass cover crops provide different benefits to subsequent cash crops. Legumes fix atmospheric $\mathrm{N}$ and generally have a tissue $\mathrm{C}: \mathrm{N}$ ratio favorable to rapid decomposition and $\mathrm{N}$ mineralization compared with a grass (Creamer and Baldwin, 2000). Grass mulch or residue is more suited to provide physical weed suppression because it decomposes more slowly, but it may also cause $\mathrm{N}$ immobilization that would adversely affect a subsequent cash crop. In a comparison of soil-incorporated summer cover crops, lettuce yield was lower after a grass than a legume cover crop, but these same plots, no-till planted in spring to muskmelon, produced equivalent melon yields that were greater than yields on bare ground (Wang et al., 2008). This suggests that the grass caused some initial $\mathrm{N}$ immobilization, yet decomposition of the residues contributed to yield of the spring crop. A useful strategy to avoid $\mathrm{N}$ tie-up is to add another $\mathrm{N}$ source to a grass cover crop.

Legume cover crops can provide some or all of the $\mathrm{N}$ required for subsequent cash crop production. A meta-analysis comparing $\mathrm{N}$ supplied by fertilizers on bare ground versus legumes grown with no additional $\mathrm{N}$ fertilizer found that if the legume biomass was sufficient (containing at least $110 \mathrm{~kg} \mathrm{~N} / \mathrm{ha}$ ), then there was no significant difference in crop yield between the two strategies (Tonitto et al., 2006). However, legume cover crops may not provide sufficient $\mathrm{N}$ for optimal yield of a subsequent vegetable crop (Abdul-Baki et al., 1997b), especially in warm temperate environments (Cherr et al., 2006b).

Supplemental N applications can be used to address the challenge of coordinating timing of $\mathrm{N}$ mineralization of plant residues to meet crop demand. Manure-based $\mathrm{N}$ fertilizers, a common organic fertility option, can lead to soil phosphorus loading with overuse. Legume seed meals have relatively high $\mathrm{N}$ content, which makes them suitable candidates for organic $\mathrm{N}$ fertility sources (Müller and von Fragstein und Niemsdorff, 2006; Stadler et al., 2006). Soybean meal is the byproduct of soybeans [Glycine $\max (\mathrm{L}$.) Merrill] pressed for oil and is a relatively concentrated source of $\mathrm{N}(8 \% \mathrm{~N})$ that can be used as an organic fertilizer (Gaskell and Smith, 2007).

Mixtures of grass and legume cover crops grown in combination can provide greater benefits than either grown alone. Grasslegume mixtures can increase cover crop biomass production compared with their respective monocultures (Sainju et al., 2005). When compared with a legume monocrop, grass-legume mixtures can provide equivalent $\mathrm{N}$ release while improving $\mathrm{N}$ use efficiency of a subsequent crop by moderating the release of cover crop N (Ranells and Wagger, 1997a, 1997b). Surface residues of grass-legume mixtures improved weed control compared with the legume monocrop without use of herbicides as measured by reduced weed emergence (Teasdale and Abdul-Baki, 1998). The relative composition 
of grass to legume in mixtures influences the overall $\mathrm{N}$ content and C: $\mathrm{N}$ ratio of the residue (Ranells and Wagger, 1997b) and therefore mixture composition could influence the effect of the cover crop residue on a subsequent crop.

Cover crop residues have the potential to reduce weed pressure, but additional weed control is often necessary. Weed control was insufficient in organic no-till pepper production using a flail-mowed legume as a mulch (Chellemi and Rosskopf, 2004) or flailmowed grass monocrop and grass-legume mixtures compared with mechanical cultivation (Díaz-Pérez et al., 2008). However, in no-till desert production of bell pepper, a cowpea surface residue treatment, with or without hand weeding, had higher fruit yield than bare-ground treatments and provided sufficient season-long weed control (Hutchinson and McGiffen, 2000). A dense uniform mulch of in situ subterranean clover provided good weed control for a subsequent lettuce crop (Stirzaker et al., 1993). Cover crop mixtures suppressed weeds as effectively as a herbicide-controlled treatment for no-till tomatoes 4 weeks after transplanting (Herrero et al., 2001). Creamer et al. (1996a) reported season-long weed suppression using cover crop mixtures was equivalent to herbicide treatments with or without cover crops for no-till tomatoes. Teasdale and Mohler (2000) showed a strong positive correlation between mulch biomass (e.g., cover crop residue mulch) and weed suppression and attributed increased weed control to physical properties of the mulch on the soil surface.

Bulb onions can be fall-planted for overwintered production in the southeastern United States. The average fall frost date for eastern North Carolina is mid- or late October (Perry, 1996), which would allow for frost kill of a susceptible cover crop to correspond with onion transplanting. Onions pose a particular challenge for weed control as a result of their sparse vegetative structure, which allows for greater weed competition than crops that produce a closed canopy. Organic onions grown in Georgia are most often produced by transplanting into plastic mulch for weed control. With in situ cover crop mulch, no-till transplanting equipment can be used to cut through surface residue, create a narrow furrow for the transplant, and close the furrow with weighted press wheels (Treadwell et al., 2008).

Winter cropping using summer cover crop residue for $\mathrm{N}$ and weed suppression with surface-applied organic amendment $\mathrm{N}$ have not been thoroughly studied. Low winter temperatures slow residue decomposition, which could enhance mulch-based weed control during a season when weed pressure is generally less and could contribute to a prolonged period of $\mathrm{N}$ mineralization for cash crop uptake. This study assessed the contributions of summer annual grass and legume cover crops in different mixture ratios or monocultures and rates of soybean meal as an $\mathrm{N}$ amendment on overwintered, no-till, organically managed onion production.

\section{Materials and Methods}

Site description. The experiments were conducted in 2006-2007 and 2007-2008 at the Center for Environmental Farming Systems, Goldsboro, NC. The soil both years was predominantly Wickham loamy sand (fineloamy, mixed, thermic Typic Hapludults) with, in 2006-2007, some area in Johns sandy loam (fine-loamy, siliceous, thermic Aquic Hapludults) and in 2007-2008, some area in Lynchburg sandy loam (fine-loamy, siliceous, thermic Aeric Paleaquults). Initial soil pH was 5.9 and 5.5 in 2006-2007 and 20072008 , respectively. At the start of the 2007 2008 experiment, lime was applied at $2.2 \mathrm{t}$. $\mathrm{ha}^{-1}$ according to North Carolina Department of Agriculture and Consumer Services (NCDA\&CS) Agronomic Division soil test recommendations. The 2007-2008 site was fumigated 1 year before this experiment with methyl bromide as mandated by the NCDA\&CS for control of a federally labeled noxious weed, Benghal dayflower (Commelina benghalensis L.). Preceding crops in the 2006-2007 and 2007-2008 sites were wheat (Triticum aestivum L.) and rye (Secale cereale L.), respectively. Neither site was managed for organic production before this experiment and therefore treatment effects can be interpreted as representing transitional organic systems.

Experimental design. Cover crop treatments were grown during the summer (from July through October) followed by no-till transplanted onions in the fall for overwinter production (from November to May). The field experiment was managed according to the U.S. National Organic Program production standards (USDA Agricultural Marketing Service, 2006).

The study was a split plot on a randomized complete block design with six replications. Main treatment cover crop plots were divided into three $\mathrm{N}$ rate subplots. Cover crop treatments were: 1) foxtail millet 'German Strain R' [Setaria italica (L.) Beauv.] (MIL); 2) cowpea 'Iron \& Clay' [Vigna unguiculata (L.) Walp.] (COW); 3) mixtures of millet and cowpea (three treatments); and 4) a bare ground control (BG). The three mixture treatments differed in seeding rates of millet, which were aimed at producing $70 \%, 50 \%$, and $30 \%$ millet per total mixture biomass at cover crop maturity (MIX-70, MIX-50, and MIX-30, respectively). After onion transplanting, three $\mathrm{N}$ rate treatments of soybean meal containing 0,105 , and $210 \mathrm{~kg} \mathrm{~N} /$ ha were applied to each cover crop treatment.

Cover crop management. Field preparations in July, of each year, included tillage necessary to incorporate residue from previous grain crops and preparation of a uniform seedbed for cover crop seeding. Nitrogen fertility for the cover crops was applied in the form of stockpiled turkey litter (3.5\% and 4.4\% $\mathrm{N}$ in 2006-2007 and 2007 2008 , respectively) with a manure spreader truck at $\approx 4.5 \mathrm{t} \cdot \mathrm{ha}^{-1}$ according to NCDA\&CS Agronomic Division soil test recommendations. Turkey litter was incorporated before shaping raised beds $10 \mathrm{~cm}$ high and $1.2 \mathrm{~m}$ wide on 1.9-m centers in 2006-2007 and ground-level beds with the same dimensions in 2007-2008. Main plots consisted of one bed, 23 and $18 \mathrm{~m}$ long in 2006-2007 and 2007-2008, respectively, which were divided into three subplots along the length of the bed. Cover crops were seeded on bed tops in six rows $20 \mathrm{~cm}$ apart with an Almaco cone seeder model BCTSMO (Almaco, Nevada, IA) on 31 July 2006 and 19 July 2007. Cover crop treatments were seeded at the following rates per bed top area: MIL $25 \mathrm{~kg} \cdot \mathrm{ha}^{-1}$, COW $85 \mathrm{~kg} \cdot \mathrm{ha}^{-1}$, and MIX cowpea at $65 \mathrm{~kg} \cdot \mathrm{ha}^{-1}$ with millet at 4,7 , and $10 \mathrm{~kg} \cdot \mathrm{ha}^{-1}$ for MIX-30, MIX-50, and MIX-70, respectively. Cowpeas were inoculated with Bradyrhizobium spp. using a slurry method before seeding.

BG plots were maintained during summer cover crop production with periodic flameweeding five times in 2006-2007 and three times in 2007-2008 before onion transplanting in the fall. Weed pressure was higher in 2006-2007 than 2007-2008.

Covers crops were flattened to the ground with a tractor-mounted roller in the third week of October and senesced after freezing night temperatures. Millet plants were severely affected during the summer growing season by Pyricularia leaf spot [Pyricularia grisea (Cke.) Sacc], which caused stunting and mortality in 2006-2007. Pyricularia leaf spot was also present in 2007-2008 but did not develop into a severe infestation, likely attributable in part to drought conditions. As a result of low millet biomass in 2006-2007, supplemental millet was added to MIL and MIX plots from an area seeded at the same time as cover crop treatments grown and baled directly adjacent to the experimental plots. After onion transplanting, millet additions were distributed by hand across the 1.2$\mathrm{m}$ width of the plot bed. The dry weight of millet was increased in MIL to the average dry tonnage of COW (4.8 th ha $\left.{ }^{-1}\right)$ and in one MIX plot per repetition to achieve $50 \%$ of the respective total cover crop biomass (a formulated MIX-50).

Onion production. An Organic Materials Review Institute-approved potassium sulfate $\left(\mathrm{K}_{2} \mathrm{SO}_{4}\right)$ was applied at $43 \mathrm{~kg} \cdot \mathrm{ha}^{-1}$ and 63 $\mathrm{kg} \cdot \mathrm{ha}^{-1}$ of potassium (based on NCDA\&CS Agronomic Division soil test recommendations for 2006-2007 and 2007-2008, respectively) in the fourth week of October each year.

Eight-week-old 'Texas Grano 1015Y' onion seedlings were transplanted during the first week of November in both 20062007 and 2007-2008. Onion seedlings were planted in three rows $38 \mathrm{~cm}$ apart on the bed with $10-\mathrm{cm}$ in-row spacing using a subsurface tiller-transplanter (SST-T Model 2000; B\&B No-Till, Laurel Fork, VA) with modified Holland Transplanter Model 1600 units (Holland Transplanter Co., Holland, MI).

$\mathrm{N}$ rate treatments were applied close to 4 weeks after onion transplanting using soybean meal at rates of 0,105 , and $210 \mathrm{~kg} \mathrm{~N} / \mathrm{ha}$. These $\mathrm{N}$ rates were chosen as $0 \%, 75 \%$, and $150 \%$ of the total $\mathrm{N}$ fertilizer $\left(140 \mathrm{~kg} \cdot \mathrm{ha}^{-1}\right)$ 
recommendation for bulb onion production in the southeastern United States (Sanders, 2004). A $0 \mathrm{~kg} \cdot \mathrm{ha}^{-1} \mathrm{~N}$ rate was included to evaluate the $\mathrm{N}$ contribution from cowpea residue. An $\mathrm{N}$ rate exceeding the recommended rate was included to compensate for potential incomplete soybean meal $\mathrm{N}$ mineralization and $\mathrm{N}$ immobilization from millet residue. Soybean meal $(8.2 \% \mathrm{~N})$ was surfaceapplied on 28 Nov. and 29 Nov. in 20062007 and 2007-2008, respectively, at 0.85 and $1.7 \mathrm{t} \cdot \mathrm{ha}^{-1}$ uniformly across the $1.2-\mathrm{m}$ wide bed-top area for the 105 and $210 \mathrm{~kg} \mathrm{~N} / \mathrm{ha}$ treatment subplots, respectively. Target $\mathrm{N}$ rates (105 and $210 \mathrm{~kg} \cdot \mathrm{ha}^{-1}$ ) were thus achieved on a bed-top area basis.

Each subplot had a 4.3-m length of bed that was hand-weeded twice during onion cropping, whereas the remainder of the subplot was left weedy to evaluate the weed suppression potential of each cover crop treatment. Data were collected from the center $3 \mathrm{~m}$ of the weeded area so as to have weeded buffer areas. The first weed control event was 15 Jan. and 10 Jan. and the second weeding on 22 Mar. and 15 Apr. in 2006 2007 and 2007-2008, respectively. Hand pulling of weeds minimized disturbance of cover crop residues.

Onions were overhead-irrigated as needed each year. Onions were harvested in late May each year, $205 \mathrm{~d}$ after transplanting.

\section{Data collection}

Cover crop biomass and nitrogen. Cover crop biomass was measured for each treatment after roll-down from a frame $0.5 \mathrm{~m}^{2}$ in 2006-2007 and $1.0 \mathrm{~m}^{2}$ in 2007-2008. Each biomass sample was separated into component cover crop species and weeds. All cover crop biomass was dried at $60{ }^{\circ} \mathrm{C}$ for $48 \mathrm{~h}$, weighed, ground, and analyzed for total $\mathrm{N}$ and carbon (C) on a Perkin-Elmer $2400 \mathrm{CHN}$ elemental analyzer (Perkin Elmer Corp., Norwalk, CT). In 2006-2007, supplemental millet was sampled with a bale corer from the middle of bale ends for total $\mathrm{N}$ and $\mathrm{C}$ analysis using the same procedure.

Soil sampling. Soil mineral N status was evaluated for all cover crop treatments on three different dates relative to onion production: preplant (at cover crop maturity in October), bulb initiation (March), and onion harvest (May). In 2007-2008, a fourth sampling date was added midseason (February). Additionally, soil sampling events were conducted on BG treatment $\mathrm{N}$ rate subplots every 2 weeks from application of soybean meal until onion harvest. Soil samples from separate 0 - to $15-\mathrm{cm}$ and $15-$ to $30-\mathrm{cm}$ depths consisted of three soil cores taken within 10 $\mathrm{cm}$ of each onion row. Soil samples were air-dried on greenhouse benches, fumigated with methyl bromide (to prevent spread of C. benghalensis seeds), homogenized, and extracted with $1 \mathrm{M} \mathrm{KCl}$. Extracts were analyzed for $\mathrm{NH}_{4}{ }^{+}-$and $\mathrm{NO}_{3}{ }^{-} \mathrm{N}$ using flow injection analysis methods for colorimetric determination with a QuikChem IV (Lachat Instruments, Loveland, $\mathrm{CO}$ ). The sum of $\mathrm{NH}_{4}{ }^{+}$ and $\mathrm{NO}_{3}{ }^{-}$is presented as total soil inorganic $\mathrm{N}$.
Weed evaluation. Weed evaluations included percent weed cover and weed density taken before each of the two weeding events in the weeded area of subplots. Percent weedy cover was evaluated using a modified Braun-Blanquet cover-abundance scale that rated the percent of ground surface area covered by weed foliage in the following categories of percent weeds: $2.5 \%$ or less, $2.5 \%$ to $5 \%, 5 \%$ to $10 \%, 10 \%$ to $25 \%, 25 \%$ to $50 \%$, and $50 \%$ to $75 \%$. Weed density was taken from $0.5 \mathrm{~m}^{2}$ in $2006-2007$ and $3.7 \mathrm{~m}^{2}$ in 2007-2008.

Onion yield. Onions were harvested by hand from $3 \mathrm{~m}$ of bed in weeded areas of each subplot and separately from $0.6 \mathrm{~m}$ of bed in the weedy area of subplots. As a result of high rates of onion flowering each year (average bolting rates of $28 \%$ and $72 \%$ in $2006-2007$ and 2007-2008, respectively), bolted onions were harvested for data collection. During field harvest, roots were trimmed and stems cut at $5 \mathrm{~cm}$ above the bulb. Bulbs were airdried under shelter with through breezes for up to 1 week. Onion bulbs were graded in accordance with the U.S. grade standards for Granex type onions as marketable (U.S. No. 1, U.S. No. 2) or cull (primarily bolted onions) and into size classifications (USDA, 1995). Size classes were determined by equatorial diameter as small (less than $5 \mathrm{~cm}$ ), medium $(5.0$ to $7.6 \mathrm{~cm})$, or large (greater than $7.6 \mathrm{~cm}$ ). After drying, all bulbs were counted and weighted, and marketable onions were sized. Bulb tissue $\mathrm{N}$ was determined from eight to 12 marketable bulbs from which wedges were cut, dried, ground, and analyzed for total $\mathrm{N}$ content by frontal chromatography with a Perkin-Elmer $2400 \mathrm{CHN}$ elemental analyzer (Perkin Elmer Corp.).

Statistical analysis. Data were analyzed with analysis of variance using PROC GLM and PROC MIXED [Version 9.1; Statistical Analysis Systems (SAS Inc., Cary, NC), 2007]. Mean comparisons were generated using Fisher's protected least significant difference $(P \leq 0.05)$. As a result of significant treatment-by-year interactions, data were analyzed separately by year.
$\mathrm{N}$ rates from 0 to $210 \mathrm{~kg} \mathrm{~N} /$ ha generally had a positive linear effect on onion yield, and several onion yield variables showed significant cover crop by $\mathrm{N}$ rate interactions. Onion yield data were therefore analyzed for $\mathrm{N}$ rate linear and quadratic effects on cover crop treatments. Three orthogonal contrasts were run to compare 1) MIL versus COW; 2) MIL versus MIX-50; and 3) COW versus BG. The same three contrasts were run to compare their respective $\mathrm{N}$ rate linear and $\mathrm{N}$ rate quadratic effects. $\mathrm{N}$ rate quadratic contrasts were nonsignificant for variables analyzed unless otherwise noted.

\section{Results and Discussion}

Weather. The 2006-2007 experiment was characterized by unusually wet conditions during cover crop production (rainfall in Sept. through Oct. 2006 was $200 \mathrm{~mm}$ greater than the 30-year monthly averages from 1971 to 2000) and unusually dry conditions during spring onion production (rainfall in Jan. through May 2007 was $180 \mathrm{~mm}$ less than the 30-year average) (Fig. 1). The 2007-2008 experiment was characterized by drought conditions during cover crop growth (rainfall in Aug. through Sept. 2007 was $160 \mathrm{~mm}$ below the 30 -year average). Onion production in 2006-2007 and cover crop growth in 2007-2008 were affected by the 6 months from Apr. to Sept. 2007, which were the driest on record for North Carolina and compounded moisture deficits since Jan. 2007 (National Climatic Data Center, 2007).

Cover crop and weed biomass at cover crop maturity. In both experiments (20062007 and 2007-2008), cowpea biomass was in the expected range or higher, whereas millet biomass was low, especially in 20062007 (Table 1). Cowpea biomass at maturity is typically in the range of 2.8 to $5.0 \mathrm{t} \cdot \mathrm{ha}^{-1}$, and cowpea 'Iron \& Clay' grown in eastern North Carolina had biomass of $4.0 \mathrm{t} \cdot \mathrm{ha}^{-1}$ (Bowman et al., 1998; Creamer and Baldwin, 2000). Foxtail millet grown for forage generally produces 6.7 to $9.9 \mathrm{t} \cdot \mathrm{ha}^{-1}$ biomass, and German foxtail millet grown in eastern North

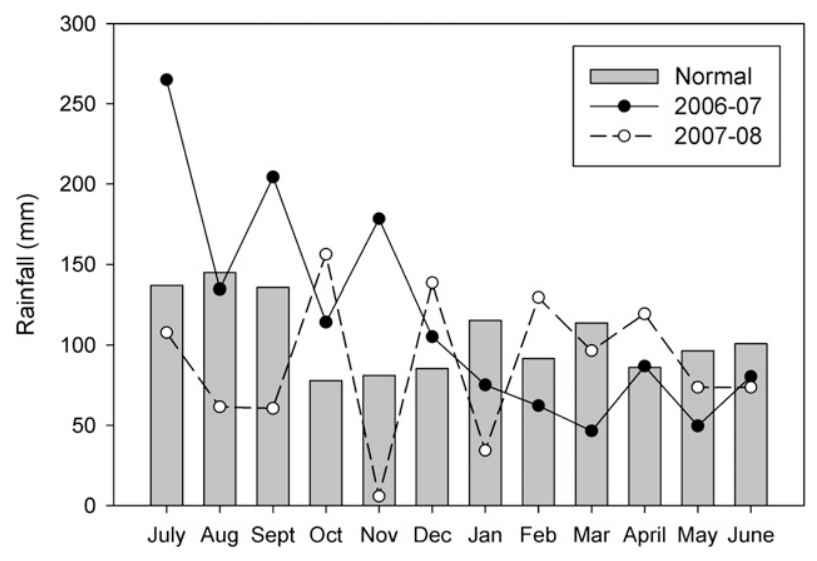

Fig. 1. Monthly rainfall at Goldsboro, NC. The 30-year normal represents 1971-2000 historical climate normals calculated by the National Climatic Data Center on a monthly basis for the Goldsboro 4 SE weather station. 
Carolina had biomass of $4.6 \mathrm{t} \cdot \mathrm{ha}^{-1}$ (Creamer and Baldwin, 2000; Oelke et al., 1990).

In 2006-2007, after supplemental millet was applied to MIL and MIX treatment plots, total cover crop biomass was highest for MIX and equivalent for MIL and COW, whereas in 2007-2008, total cover crop biomass was equivalent across all cover crop treatments (Table 1). Cover crop $\mathrm{N}$ concentration averaged $20 \mathrm{~g} \mathrm{~N} / \mathrm{kg}$ for both millet and cowpea in 2006-2007, whereas in 2007-2008, millet and cowpea averaged 14 and $19 \mathrm{~g} \mathrm{~N} / \mathrm{kg}$, respectively. Millet N concentrations were higher than found in other studies in which millet had $10 \mathrm{~g} \mathrm{~N} / \mathrm{kg}$ (Abdul-Baki et al., 1997a; Creamer and Baldwin, 2000). Total
$\mathrm{N}$ in cover crop residues was higher in 2006 2007 than 2007-2008 as a result of greater total biomass in 2006-2007. In 2007-2008, drought conditions caused some seedling millet mortality by 3 weeks after seeding and cowpea plants after seedling stage were heavily browsed by deer, which likely reduced final biomass despite cowpea regrowth. The $\mathrm{C}: \mathrm{N}$ ratio of all mulches except MIL in 2007-2008 was less than $30: 1$ and therefore was in the theoretical range in which net $\mathrm{N}$ mineralization occurs.

Soil nitrogen. Cover crop treatments significantly affected soil $\mathrm{N}$ at the time of onion transplanting in both experiments (Table 2). At cover crop maturity in 2006-2007, BG had the least $\mathrm{N}$ in the 0 - to $15-\mathrm{cm}$ depth but had the most $\mathrm{N}$ in the lower $15-$ to $30-\mathrm{cm}$ depth of soil. This could be attributed to residual $\mathrm{N}$ from turkey litter leaching to the lower depth where there was no cover crop vegetation $(\mathrm{BG})$. At cover crop maturity in 2007-2008, BG had the most $\mathrm{N}$ in both 0 - to 15 - and 15- to 30-cm depths compared with all other cover crop treatments. The higher levels of soil $\mathrm{N}$ (primarily $\mathrm{NO}_{3}^{-}$) on $\mathrm{BG}$ in 2007-2008 than 2006-2007 could be attributed in part to less $\mathrm{NO}_{3}{ }^{-}$leaching through the soil profile below $30 \mathrm{~cm}$ because of unusually low rainfall in the summer of 2007. In both years, turkey litter was field-applied before cover crop seeding and therefore $\mathrm{N}$ was also

Table 1. Cover crop biomass, nitrogen (N), and weed biomass at time of cover crop roll-down in 2006-2007 and 2007-2008.

\begin{tabular}{|c|c|c|c|c|c|c|c|c|c|c|c|}
\hline \multirow{4}{*}{$\frac{\text { Year }}{2006-2007}$} & \multirow[b]{3}{*}{ Treatment $^{\mathrm{v}}$} & \multicolumn{6}{|c|}{ Biomass } & \multicolumn{2}{|c|}{$\mathrm{N}$ concn $^{2}$} & \multirow{3}{*}{$\begin{array}{l}\text { N content }{ }^{\mathrm{w}} \\
\left(\mathrm{kg} \cdot \mathrm{ha}^{-1}\right)\end{array}$} & \multirow[b]{3}{*}{$\mathrm{C}: \mathrm{N}$ ratic } \\
\hline & & Millet & Cowpea & Addition $^{y}$ & Total & \multirow{2}{*}{$\begin{array}{c}\text { Percent } \\
\text { millet }\end{array}$} & \multirow{2}{*}{$\begin{array}{l}\text { Weed }^{\mathrm{x}} \\
\left(\mathrm{g} \cdot \mathrm{m}^{-2}\right)\end{array}$} & Millet & Cowpea & & \\
\hline & & \multicolumn{4}{|c|}{$\left(\mathrm{t} \cdot \mathrm{ha}^{-1}\right)$} & & & \multicolumn{2}{|c|}{$\left(\mathrm{g} \cdot \mathrm{kg}^{-1}\right)$} & & \\
\hline & MIL & 2.41 & - & 3.64 & 6.05 & - & $6.47 \mathrm{a}^{\mathrm{u}}$ & $20.4 \mathrm{a}$ & - & $123 \mathrm{~b}$ & $19.5 \mathrm{a}$ \\
\hline & COW & - & 6.08 & - & 6.08 & - & $0.02 \mathrm{~b}$ & - & $18.2 \mathrm{a}$ & $110 \mathrm{~b}$ & $21.8 \mathrm{a}$ \\
\hline \multirow[t]{3}{*}{ 2007-2008 } & MIL & 4.44 & - & - & $4.44 \mathrm{a}$ & - & $3.29 \mathrm{a}$ & $12.1 \mathrm{c}$ & - & $53 \mathrm{~b}$ & $36.9 \mathrm{a}$ \\
\hline & MIX-70 & 2.27 & 2.36 & - & $4.63 \mathrm{a}$ & 52.5 & $7.09 \mathrm{a}$ & $14.6 \mathrm{ab}$ & $18.5 \mathrm{a}$ & $77 \mathrm{a}$ & $25.3 \mathrm{~b}$ \\
\hline & COW & - & 4.54 & - & $4.54 \mathrm{a}$ & - & $0.90 \mathrm{a}$ & - & $19.4 \mathrm{a}$ & $88 \mathrm{a}$ & $20.6 \mathrm{bc}$ \\
\hline
\end{tabular}

${ }^{\mathrm{z}} \mathrm{N}$ concentration is sum of organic and inorganic $\mathrm{N}$.

${ }^{\mathrm{y}}$ Millet additions from an area seeded at the same time as cover crop treatments, grown, and baled directly adjacent to the experimental plots and distributed by hand on bed top area after onion planting.

${ }^{\mathrm{x}}$ Weed biomass variable square root transformed for homogeneity of variance before analysis and back transformed for presentation.

${ }^{\mathrm{w}}$ Total $\mathrm{N}$ in cover crop biomass, including millet additions, which had $\mathrm{N}$ concentration of $20.2 \mathrm{~g} \cdot \mathrm{kg}^{-1}$.

${ }^{\vee}$ MIL = millet; MIX-70, MIX-50, MIX-30 = cowpea with high, middle, and low seeding rates of millet, respectively; COW = cowpea.

"Mean separation within column and year by Fisher's protected least significant difference $(P \leq 0.05)$ where least significant difference letters are presented. ${ }^{\mathrm{t}} \mathrm{MIX}$ in 2006-2007 was one mixture plot per block with millet additions to adjust to target percent millet (50\%) while maintaining total biomass within a range of $2.25 \mathrm{t} \cdot \mathrm{ha}^{-1}$.

Table 2. Soil $\mathrm{N}\left(\mathrm{NH}_{4}{ }^{+}+\mathrm{NO}_{3}^{-}\right)$as affected by cover crop and nitrogen $(\mathrm{N})$ rate in 2006-2007 and 2007-2008.

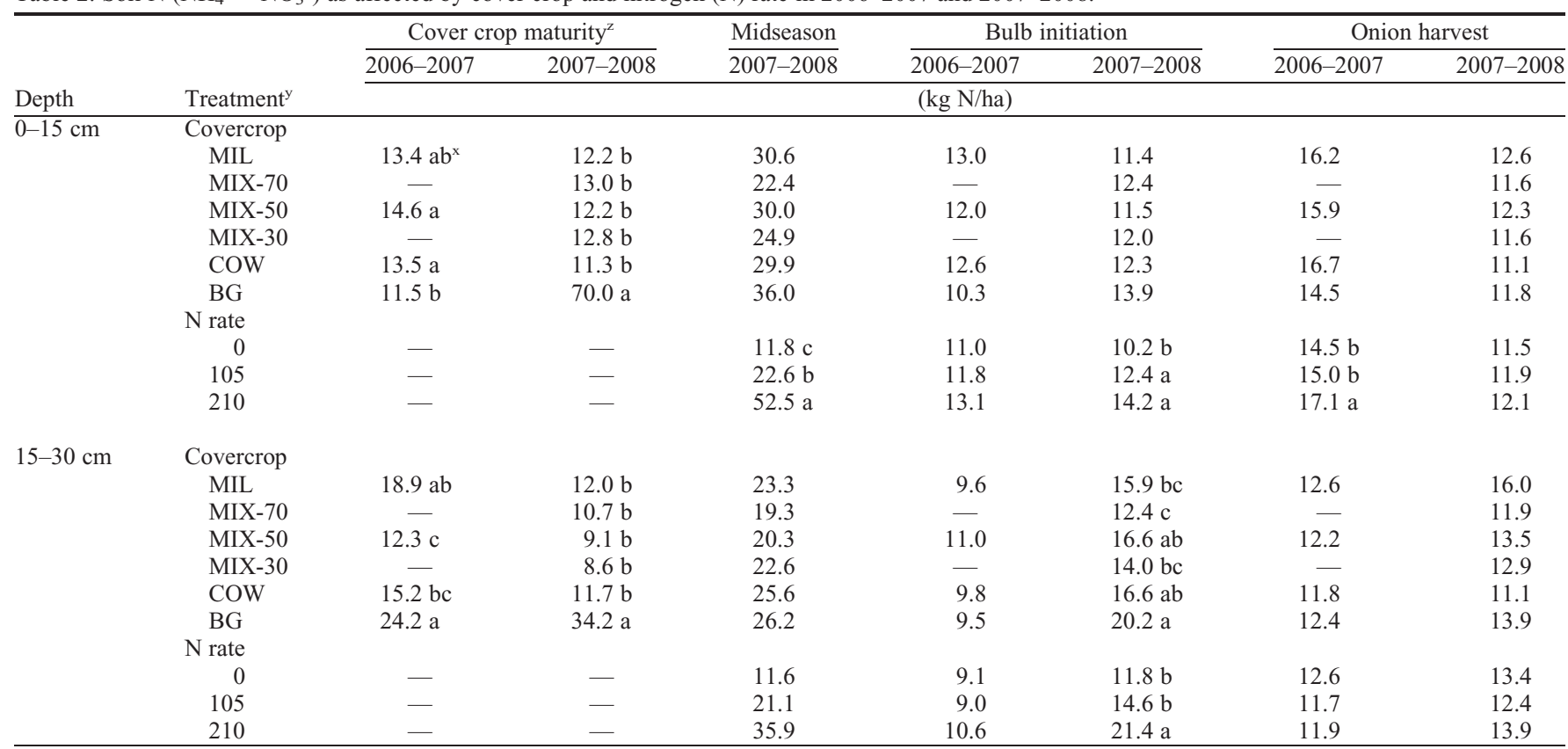

${ }^{\mathrm{z}}$ Onions were planted the first week of November each year. Soil sampling events relative to onion production were: cover crop maturity on 19 Oct. 2006 and 24 Oct. 2007; midseason on 7 Feb. 2008; bulb initiation on 27 Mar. 2007 and 21 Mar. 2008; onion harvest on 21 May 2007 and 22 May 2008 for $2006-2007$ and 2007-2008 experiments, respectively.

${ }^{\mathrm{y}} \mathrm{MIL}=$ millet; MIX-70, MIX-50, MIX-30 = cowpea with high, middle, and low seeding rates of millet, respectively; $\mathrm{COW}=$ cowpea; $\mathrm{BG}=$ bare ground. $\mathrm{N}$ rates 0 , 105 , and $210 \mathrm{~kg} \mathrm{~N} / \mathrm{ha}$ of soybean meal.

${ }^{\mathrm{x}}$ Mean separation within column and year by Fisher's protected least significant difference $(P \leq 0.05)$. 
applied on BG plots, which did not have

The effect of $\mathrm{N}$ rates on $\mathrm{BG}$ soil $\mathrm{N}$ was similar in both 2006-2007 and 2007-2008 (Figs. 2 and 3). Within 2 weeks of the surface application of soybean meal in late November, there was a significant difference among gests that $\mathrm{N}$ was being mineralized from the soybean meal even in the cool weather of early December. At 2 weeks after soybean meal application in 2006-2007, there was also a significant $\mathrm{N}$ rate effect on soil $\mathrm{N}$ at the 15- to 30-cm depth, whereas in 2007-2008, significant differences in the $15-$ to $30-\mathrm{cm}$ depth were not apparent until 8 weeks after application (late January). Soybean meal application (105 and $210 \mathrm{~kg} \mathrm{~N} / \mathrm{ha}$ ) increased soil $\mathrm{N}$ compared with the $0 \mathrm{~N}$ treatment for the duration of at least 2 months in 20062007 and nearly 3 months in 2007-2008 (through late Feb. 2008) in the 0- to $15-\mathrm{cm}$ a cover crop that would take up soil $\mathrm{N}$. $\mathrm{N}$ rates in the 0 - to $15-\mathrm{cm}$ depth, which sug-

depth. In Mar. 2008 (2007-2008 experiment), there was a significant $\mathrm{N}$ rate effect on soil $\mathrm{N}$ in both depths when considered across all cover crop treatments (Table 2) but not on BG alone (Fig. 3).

The increased soil mineral $\mathrm{N}$ in the 15 - to $30-\mathrm{cm}$ depth where soybean meal was applied (105 and $210 \mathrm{~kg} \mathrm{~N} / \mathrm{ha}$ rates) on BG indicates that $\mathrm{N}$ was moving through the soil horizon from surface-applied soybean meal (Figs. 2 and 3). Onion plants were still small at this time and therefore some $\mathrm{N}$ from soybean meal mineralization was possibly lost below the shallow onion root zone or immobilized, especially in the $210 \mathrm{~kg} \mathrm{~N} / \mathrm{ha}$ treatment. Early in the onion production season, the $105 \mathrm{~kg} \mathrm{~N} /$ ha rate caused less of an increase in soil $\mathrm{N}$ in the lower 15 - to $30-\mathrm{cm}$ depth than the $210 \mathrm{~kg} \mathrm{~N} / \mathrm{ha}$ rate and therefore could possibly be used as a starter fertilizer that would minimize $\mathrm{N}$ leaching. Recommended $\mathrm{N}$ application at transplanting for

\section{6-07}
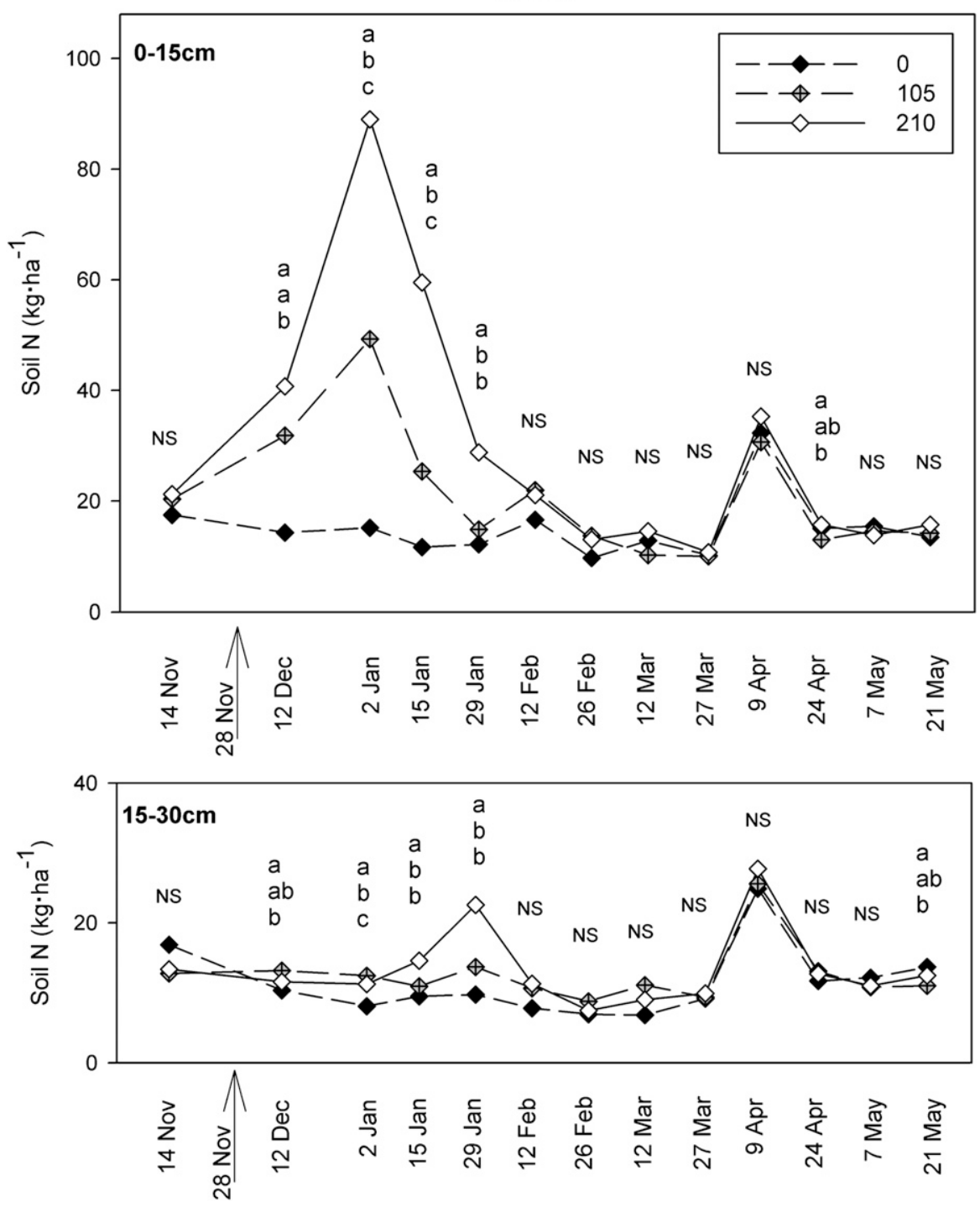

Fig. 2. Soil $\mathrm{N}\left(\mathrm{NH}_{4}{ }^{+}+\mathrm{NO}_{3}{ }^{-}\right)$of $\mathrm{BG}$ (bare-ground treatment) by nitrogen (N) rates 0,105 , and $210 \mathrm{~kg} \mathrm{~N} / \mathrm{ha}$ of soybean meal at 0 - to $15-\mathrm{cm}$ and $15-$ to $30-\mathrm{cm}$ depths across 2006-2007 sampling dates. Soybean meal was applied on 28 Nov. 2006. Mean separation within date and depth by Fisher's protected least significant difference $(P \leq 0.05)$. bulb onion production is 56 to $84 \mathrm{~kg} \mathrm{~N} / \mathrm{ha}$ with an additional 28 to $56 \mathrm{~kg} \mathrm{~N} /$ ha sidedress at least 1 month after transplanting or several sidedress applications spaced 1 month apart during active growth in the spring (Sanders, 2004).

Late in the onion production season, there were a few instances when $\mathrm{N}$ rate had a significant effect on soil $\mathrm{N}$ (Table 2; Figs. 2 and 3 ). This suggests that additional $\mathrm{N}$ was being mineralized from the remaining soybean meal over time and was perhaps aided by higher temperatures in late spring.

Weed evaluations. In 2006-2007, the predominant weeds were henbit (Lamium amplexicaule L.) and cutleaf evening primrose (Oenothera laciniata Hill). At the first weeding in 2006-2007 (15 Jan. 2007), the greatest weed interference was in COW, which had the highest weed cover and high weed density (Table 3). BG had high weed density equivalent with COW but had lower percent weed cover. At that time, weed interference was also greater in treatments in which soybean meal had been applied (105 and $210 \mathrm{~kg} \mathrm{~N} / \mathrm{ha}$ ), which had greater percent weed cover than the $0 \mathrm{~N}$ rate. This suggests that $\mathrm{N}$ was being mineralized from soybean meal and cowpea residue in the months of December and January, which was contributing to weed growth. MIX and MIL treatments had more residue remaining on the soil surface than COW in mid-January (2006-2007) and weed suppression could be attributed to physical cover from the millet residue.

By the second weeding in 2006-2007 (Mar. 2007), weed density and percent weed cover were not different among cover crop treatments, but the $0 \mathrm{~N}$ rate again had the highest weed density (Table 3 ). Weeds on $0 \mathrm{~N}$ rate treatments were generally smaller than weeds on 105 and $210 \mathrm{~kg} \mathrm{~N} / \mathrm{ha}$ rate treatments on both weeding dates, and therefore higher weed density did not equate to greater percent weed cover. Total weed densities were lower by half or more for all cover crop treatments at the second weeding compared with the first weeding.

In 2007-2008, the predominant weed was rye (Secale cereale L.) and by the second weeding date (March) in weed-controlled areas, purple cudweed (Gnaphalium purpureum L.) and horseweed [Conyza canadensis (L.) Cronquist] were more prevalent than other weeds. At both the first and second weeding events in 2007-2008 (Jan. and Apr. 2008), BG had the lowest weed interference (Table 3). In 2007-2008, overall weed densities remained low at both weeding dates. Low weed density on BG in 2007-2008 compared with 2006-2007 could be attributed to recent soil fumigation.

In weedy areas of each subplot at onion harvest, weeds nearly completely covered the ground.

Onion mortality. Onion mortality was over $50 \%$ in MIL and MIX plots in 20062007 (Table 4). In 2007-2008, onion mortality was close to zero except for MIL at 105 and $210 \mathrm{~kg} \mathrm{~N} / \mathrm{ha}$ rates but even then, mortality was below $20 \%$. After the second week in 
2007-08
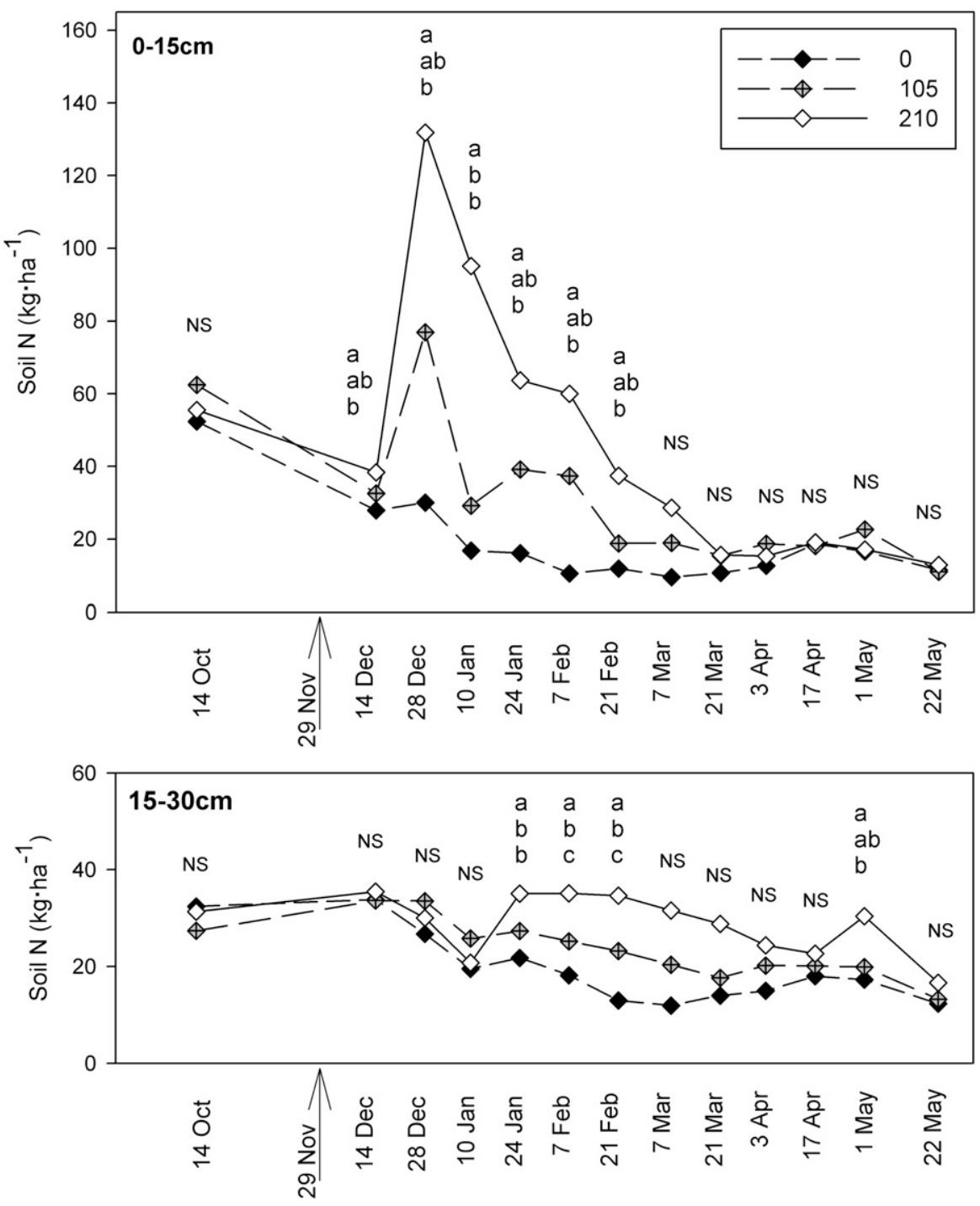

Fig. 3. Soil $\mathrm{N}\left(\mathrm{NH}_{4}^{+}+\mathrm{NO}_{3}^{-}\right)$of $\mathrm{BG}$ (bare-ground treatment) by nitrogen (N) rates 0,105 , and $210 \mathrm{~kg} \mathrm{~N} / \mathrm{ha}$ of soybean meal at 0 - to $15-\mathrm{cm}$ and $15-$ to $30-\mathrm{cm}$ depths across 2007-2008 sampling dates. Soybean meal was applied on 29 Nov. 2007. Mean separation within date and depth by Fisher's protected least significant difference $(P \leq 0.05)$.

Dec. 2006 (2006-2007 experiment), after freezing night temperatures down to $-9{ }^{\circ} \mathrm{C}$, cold injury on onion plants was obviously more severe on MIL and MIX plots than COW and BG (visual observation). In Dec. 2007 (2007-2008 experiment), temperatures dropped below $-8{ }^{\circ} \mathrm{C}$ and cold damage appeared to be more severe in some areas on MIL plots where residue was thick and close on either side of the onion row than on other cover crop treatments. Residue coverage on MIL in 2006-2007 was very uniform across the bed top and around onion transplants as a result of hand application of supplemental millet. In contrast, MIL in 2007-2008 had strips of bare ground exposed as a result of millet seeded in rows and rolled down parallel to those rows. The physical thickness of the millet mulch, compared with cowpea mulch or no mulch, likely reduced absorption of heat during the day and heat radiation at night that would have contributed to formation of frost, which explains the increased plant freeze injury (Downer et al., 2002).

After onion mortality in Dec. 2006-2007, remaining MIL and MIX treatment onions exhibited uneven growth and plant size. A follow-up study in 2006-2007 assessed the presence of water-soluble allelopathic compounds in the baled millet, which was used to supplement MIL and MIX plots. Baled millet was tested as either unmodified or rinsed in water for $20 \mathrm{~h}$ (Creamer et al., 1996b) and compared with a bare surface control treatment in the field (five replications) and in greenhouse flats (six replications) planted with onion seedlings and grown for 8 weeks. No onion growth differences were apparent between the unmodified and rinsed millet mulch treatments, both of which outperformed the bare surface treatment in terms of plant weight and onion mortality in the greenhouse and field, respectively (data not shown).
Onion yield. Sweet onions such as 'Texas Grano $1015 \mathrm{Y}$ ' are sold by weight and size grades determined by bulb diameter. As presented here, marketable onion yield does not include small onions (less than $5.0 \mathrm{~cm}$ diameter), whereas total bulb yield includes small and bolted onions. Marketable onion yield showed a significant cover crop by $\mathrm{N}$ rate interaction in 2006-2007 but not in 2007-2008, although both years, there was a highly significant linear response to $\mathrm{N}$ rate (Table 5; Fig. 4). Although BG had higher large-grade onion yield than COW in 20062007 , the contrast of COW versus BG total marketable yield showed them to be equivalent both years. In 2007-2008, total marketable weight across $\mathrm{N}$ rates was highest with BG, COW, and MIX-30, which were significantly greater than MIL.

Losses in marketable yield were primarily the result of mortality in MIL and MIX in 2006-2007 and bolting across all cover crop treatments, particularly in 2007-2008. Marketable yields represented a greater proportion of total bulb yield, $70 \%$ versus $24 \%$, in 2006-2007 compared with 2007-2008 (Fig. 4 ). The highest marketable yield was over $30 \mathrm{t} \cdot \mathrm{ha}^{-1}$ in 2006-2007 but was less than $12 \mathrm{t} \cdot \mathrm{ha}^{-1}$ in 2007-2008. Variety trials conducted in Georgia showed 'Texas Grano $1015 \mathrm{Y}$ ' with a marketable (medium and large grade) yield of $5.7 \mathrm{t} \cdot \mathrm{ha}^{-1}$ out of a total bulb yield of $22.8 \mathrm{t} \cdot \mathrm{ha}^{-1}$ (Boyhan et al., 2005). However, much higher 'Texas Grano 1015Y' yields were obtained in a study in Florida where total bulb yield reached $41.2 \mathrm{t} \cdot \mathrm{ha}^{-1}$ with over $80 \%$ medium- and large-grade onions (Sargent et al., 2001).

Onion bolting reduced marketable yield in both 2006-2007 and 2007-2008. In 20072008 , bolting rates were greater than $50 \%$ for all treatments (Fig. 5). In both 2006-2007 and 2007-2008, the contrast of MIL versus COW showed that MIL had a lower rate of bolting and a shallower $\mathrm{N}$ rate linear effect on bolting (Table 5). MIL had significantly less bolting than all other cover crop treatments in 2007-2008. Flower initiation in onions is influenced by onion cultivar, plant size or age, and several environmental factors, including photoperiod, temperature, and plant $\mathrm{N}$ status. Onion juvenility lasts until the plants reach a certain critical size and is often measured in terms of plant weight or number of leaves. A postjuvenile onion plant is receptive to vernalization, which is essential for floral initiation, and the rate of flower initiation increases with plant size (Brewster, 2008). Although not quantified in this experiment, decomposition of cover crop residues could have influenced midseason onion plant size and in turn differing rates of flower initiation. $\mathrm{N}$ immobilization from MIL in 2007-2008, which had an initial C:N ratio over $37: 1$, could have contributed to smaller midseason plant size in MIL and in turn reduced the rate of bolting.

$\mathrm{N}$ rate had a significant negative linear effect on bolting from 0 to $210 \mathrm{~kg} \mathrm{~N} / \mathrm{ha}$ in both years (Table 5; Fig. 5). This finding corresponds with other studies that found 
Table 3. Weed density and percent cover before weeding events and onion harvest as affected by nitrogen (N) rate in 2006-2007 and 2007-2008.

\begin{tabular}{|c|c|c|c|c|c|c|c|c|}
\hline \multirow{2}{*}{ Treatment ${ }^{\mathrm{w}}$} & \multicolumn{4}{|c|}{ First weeding ${ }^{z}$} & \multicolumn{4}{|c|}{ Second weeding } \\
\hline & \multicolumn{2}{|c|}{ Density $^{\mathrm{y}}\left(\mathrm{m}^{-2}\right)$} & \multicolumn{2}{|c|}{ Percent cover ${ }^{\mathrm{X}}$} & \multicolumn{2}{|c|}{ Density $\left(\mathrm{m}^{-2}\right)$} & \multicolumn{2}{|c|}{ Percent cover } \\
\hline \multicolumn{9}{|l|}{ Cover crop } \\
\hline MIX-70 & - & $8.2 \mathrm{ab}$ & - & $7.0 \mathrm{a}$ & - & $15.3 \mathrm{a}$ & - & $5.5 \mathrm{bc}$ \\
\hline MIX-50 & $41 \mathrm{~b}$ & $7.3 \mathrm{ab}$ & $9.0 \mathrm{~b}$ & $4.8 \mathrm{~b}$ & 23.6 & $14.5 \mathrm{ab}$ & 7.0 & $6.5 \mathrm{ab}$ \\
\hline MIX-30 & - & $9.3 \mathrm{a}$ & - & $8.0 \mathrm{a}$ & - & $15.8 \mathrm{a}$ & - & $5.0 \mathrm{bc}$ \\
\hline COW & $126 \mathrm{a}$ & $7.0 \mathrm{ab}$ & $23.5 \mathrm{a}$ & $4.8 \mathrm{~b}$ & 40.8 & $12.7 \mathrm{~b}$ & 13.0 & $4.3 \mathrm{~cd}$ \\
\hline 0 & $120 \mathrm{a}$ & $6.9 \mathrm{ab}$ & $8.5 \mathrm{~b}$ & $3.8 \mathrm{c}$ & $55.4 \mathrm{a}$ & 13.2 & $10.0 \mathrm{a}$ & $4.5 \mathrm{~b}$ \\
\hline 105 & $87 \mathrm{~b}$ & $8.3 \mathrm{a}$ & $16.0 \mathrm{a}$ & $6.5 \mathrm{a}$ & $22.2 \mathrm{~b}$ & 12.0 & $7.0 \mathrm{~b}$ & $6.0 \mathrm{a}$ \\
\hline 210 & $73 \mathrm{~b}$ & $5.4 \mathrm{~b}$ & $14.5 \mathrm{a}$ & $4.8 \mathrm{~b}$ & $20.6 \mathrm{~b}$ & 12.3 & $8.0 \mathrm{ab}$ & $6.5 \mathrm{a}$ \\
\hline Statistics & \multicolumn{8}{|c|}{ Significance } \\
\hline Cover crop (C) & $* * *$ & $* * *$ & * & * & NS & $* * *$ & NS & * \\
\hline $\mathrm{N}$ rate $(\mathrm{N})$ & $* * *$ & $* *$ & $* *$ & $* * *$ & $* * *$ & NS & $*$ & $* *$ \\
\hline
\end{tabular}

${ }^{\mathrm{z}}$ The first weeding took place on 15 Jan. 2007 and 10 Jan. 2008 and the second weeding on 22 Mar. 2007 and 15 Apr. 2008 in the $2006-2007$ and $2007-2008$ experiments, respectively.

${ }^{\mathrm{y}}$ Weed density variables for both weeding events both years were square root transformed for homogeneity of variance before analysis and back transformed for presentation.

${ }^{\mathrm{x}}$ Statistical analysis was performed on class ratings of a modified Braun-Blanquet scale. Values presented are rate class means converted to a percent weedy cover scale.

${ }^{\mathrm{w}} \mathrm{MIL}=$ millet; MIX-70, MIX-50, MIX-30 = cowpea with high, middle, and low seeding rates of millet, respectively; $\mathrm{COW}=\mathrm{cowpea} ; \mathrm{BG}=$ bare ground. $\mathrm{N}$ rates 0,105 , and $210 \mathrm{~kg} \mathrm{~N} / \mathrm{ha}$ of soybean meal.

'Mean separation within column and year by Fisher's protected least significant difference $(P \leq 0.05)$.

Ns, ${ }^{*}, * *, * *$ Nonsignificant or significant at $P \leq 0.05,0.01$, and 0.0001 , respectively.

Table 4. Percent mortality, total yield mean bulb weight, and nitrogen (N) concentration of marketable bulbs as affected by N rate and cover crop in $2006-2007$ and $2007-2008$.

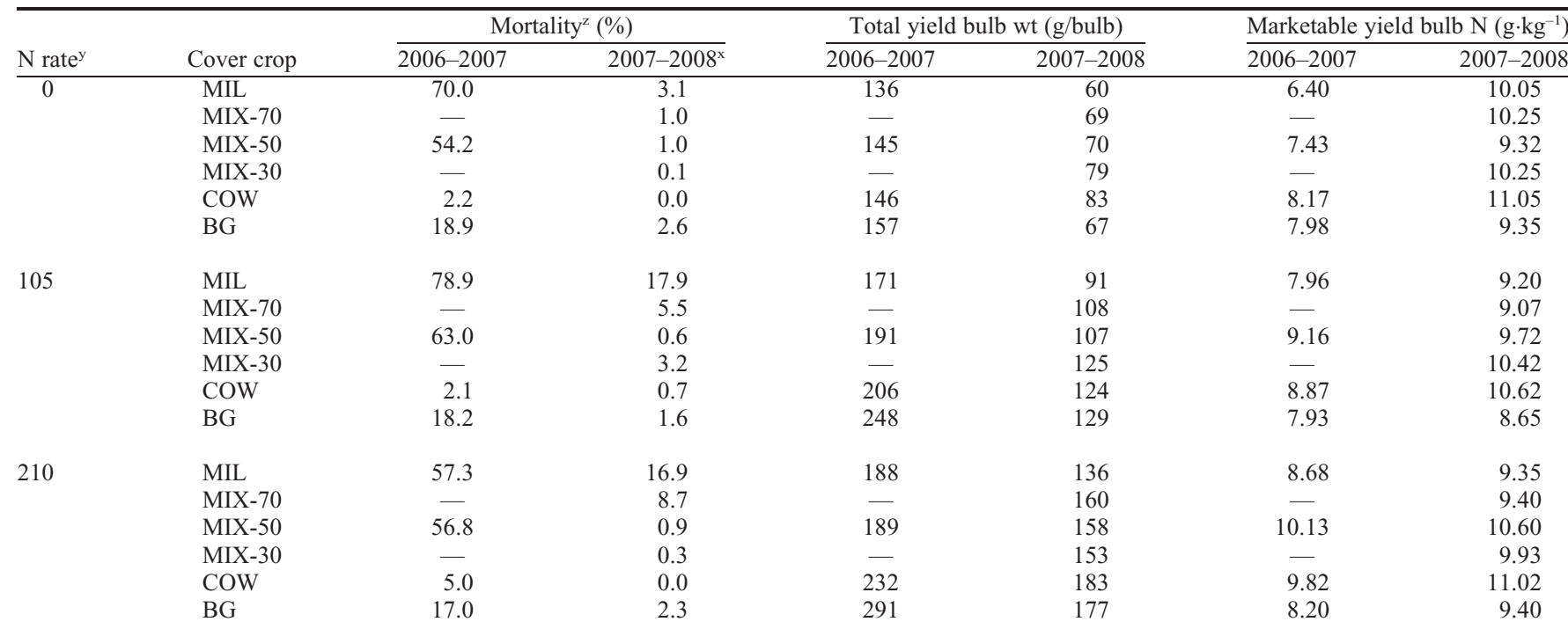

Statistics

Cover crop (C)

$\mathrm{N}$ rate $(\mathrm{N})$

$\mathrm{C} \times \mathrm{N}$

$\mathrm{N}$ rate linear

$\mathrm{N}$ rate quadratic

Contrast:

MIL vs. COW

MIL vs. MIX-50

COW vs. BG

$\mathrm{N}$ rate linear by

MIL vs. COW

MIL vs. MIX-50

COW vs. BG

\begin{tabular}{|c|c|}
\hline$* * *$ & - \\
\hline NS & - \\
\hline NS & - \\
\hline NS & - \\
\hline NS & - \\
\hline$* * *$ & - \\
\hline NS & - \\
\hline$* * *$ & - \\
\hline * & - \\
\hline NS & - \\
\hline NS & - \\
\hline
\end{tabular}

\begin{tabular}{|c|c|c|c|}
\hline$* *$ & $*$ & $*$ & $*$ \\
\hline$* * *$ & $* * *$ & $* * *$ & NS \\
\hline * & NS & * & NS \\
\hline$* * *$ & $* * *$ & $* * *$ & NS \\
\hline * & NS & NS & $*$ \\
\hline NS & $* *$ & $*$ & $* *$ \\
\hline NS & NS & $*$ & NS \\
\hline * & NS & $*$ & $* *$ \\
\hline NS & NS & NS & NS \\
\hline NS & NS & NS & $*$ \\
\hline * & NS & NS & NS \\
\hline
\end{tabular}

${ }^{\mathrm{z}}$ Square root transformed mortality variables for homogeneity of variance before analysis and back transformed for presentation.

${ }^{y} \mathrm{~N}$ rates $0,105,210 \mathrm{~kg} \mathrm{~N} / \mathrm{ha}$ of soybean meal. MIL = millet; MIX-70, MIX-50, MIX-30 = cowpea with high, middle, and low seeding rates of millet, respectively; $\mathrm{COW}=$ cowpea; $\mathrm{BG}=$ bare ground.

${ }^{\mathrm{x}}$ Zero mortality in several treatments in 2007-2008 precludes sufficient variance for analysis.

Ns, *,**,***Nonsignificant or significant at $P \leq 0.05,0.01$, and 0.0001 , respectively. 
Table 5. Bolting frequency, total yield, and marketable large grade and total yield significance levels of main and interaction effects of cover crop and nitrogen ( $\mathrm{N}$ ) rate in 2006-2007 and 2007-2008.

\begin{tabular}{|c|c|c|c|c|c|c|c|c|}
\hline \multirow{2}{*}{ Source $^{z}$} & \multicolumn{4}{|c|}{ Total yield } & \multicolumn{4}{|c|}{ Marketable yield } \\
\hline & \multicolumn{2}{|c|}{ Bolting (\%) } & \multicolumn{2}{|c|}{ Total $\left(\mathrm{t} \cdot \mathrm{ha}^{-1}\right)$} & \multicolumn{2}{|c|}{ Large $\operatorname{grade}^{\mathrm{y}}\left(\mathrm{t} \cdot \mathrm{ha}^{-1}\right)$} & \multicolumn{2}{|c|}{ Total $\left(\mathrm{t} \cdot \mathrm{ha}^{-1}\right)$} \\
\hline Statistics & \multicolumn{8}{|c|}{ Significance } \\
\hline $\mathrm{N}$ rate $(\mathrm{N})$ & $* *$ & $* *$ & $* * *$ & $* * *$ & $* * *$ & $* * *$ & $* * *$ & $* * *$ \\
\hline $\mathrm{C} \times \mathrm{N}$ & NS & NS & $* * *$ & $* * *$ & $* * *$ & * & $* * *$ & NS \\
\hline $\mathrm{N}$ rate linear & $* * *$ & ** & $* * *$ & $* * *$ & $* * *$ & $* * *$ & $* * *$ & $* * *$ \\
\hline $\mathrm{N}$ rate quadratic & NS & * & NS & NS & NS & NS & NS & NS \\
\hline MIL vs. MIX-50 & NS & * & NS & ** & NS & NS & NS & * \\
\hline COW vs. BG & NS & NS & NS & NS & * & NS & NS & NS \\
\hline \multicolumn{9}{|l|}{$\mathrm{N}$ rate linear by } \\
\hline MIL vs. COW & * & * & * & $* * *$ & $* *$ & * & * & * \\
\hline MIL vs. MIX-50 & NS & NS & NS & ** & NS & NS & NS & NS \\
\hline COW vs. BG & NS & NS & * & NS & $*$ & NS & NS & NS \\
\hline
\end{tabular}

${ }^{\mathrm{z}}$ Cover crops MIL $=$ millet; MIX-70, MIX-50, MIX-30 = cowpea with high, middle, and low seeding rates of millet, respectively; $\mathrm{COW}=\mathrm{cowpea} ; \mathrm{BG}=$ bare ground. $\mathrm{N}$ rates 0,105 , and $210 \mathrm{~kg} \mathrm{~N} / \mathrm{ha}$ of soybean meal.

${ }^{y}$ Square root transformed 2007-2008 large grade and 2007-2008 total marketable yield variables for homogeneity of variance before analysis and back transformed for presentation.

NS, $* * *, * *$ Nonsignificant or significant at $P \leq 0.05,0.01$, and 0.0001 , respectively.
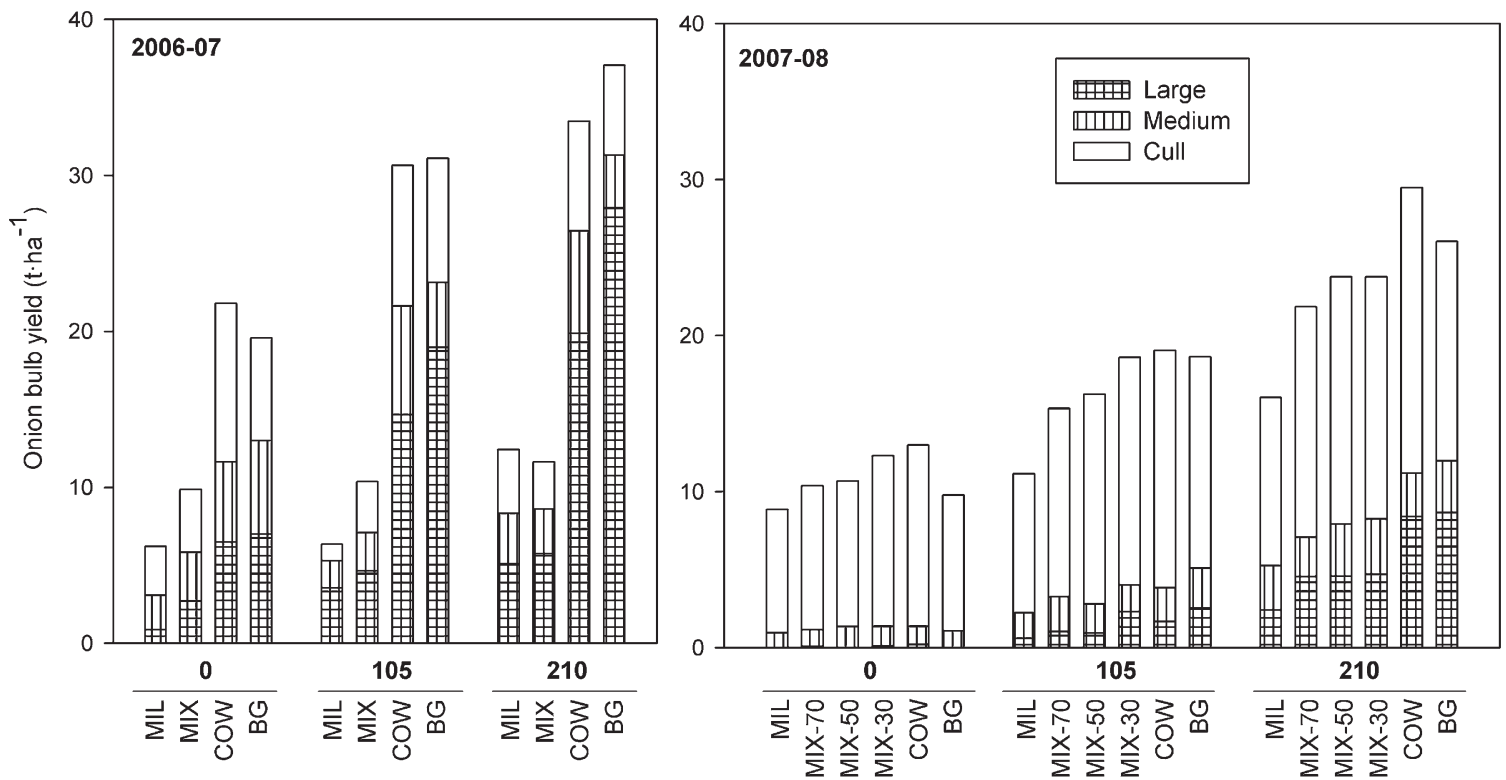

Fig. 4. Marketable large-grade onion, total marketable (medium plus large grade) and total (marketable plus cull) bulb yield as affected by nitrogen (N) rate and cover crop in 2006-2007 and 2007-2008. N rates 0,105 , and $210 \mathrm{~kg} \mathrm{~N} /$ ha of soybean meal. MIL = millet; MIX-70, MIX-50, MIX-30= cowpea with high, middle, and low seeding rates of millet, respectively; $\mathrm{COW}=$ cowpea; $\mathrm{BG}=$ bare ground.

bolting decreased with increasing fertilizer $\mathrm{N}$ rates (Díaz-Pérez et al., 2003, 2004). DíazPérez et al. (2003) showed that N concentration in bulb tissue had a positive linear correlation with rate of $\mathrm{N}$ fertilization and further that bolting decreased with increasing bulb $\mathrm{N}$ up to $1.7 \%$ bulb $\mathrm{N}$ and then leveled off. Although there was a significant linear correlation between increasing $\mathrm{N}$ rates $(0$ to $210 \mathrm{~kg} \mathrm{~N} / \mathrm{ha}$ ) and bulb $\mathrm{N}$ in 2006-2007, N rate was not significant in 2007-2008 (Table 4). Furthermore, there was no apparent linear relationship between bulb $\mathrm{N}$ and rate of bolting either year.

Onion yield in weedy areas of subplots was prohibitively low as a result of intense weed interference. In both years, marketable onion weight was less than $1 \mathrm{t} \cdot \mathrm{ha}^{-1}$ for all weedy cover crop and $\mathrm{N}$ rate treatments (data not shown).

\section{Conclusions}

Cowpea shows promise as a summer cover crop used as a residue-mulch for fallplanted crops such as overwintered onion. COW produced comparable onion yields to $\mathrm{BG}$ in both years of this experiment.

In commercial operation, weed control for large-scale organic production using in situ cover crop residues would be a major challenge and expense. Management to reduce weed seed banks and careful selection of lowweed pressure fields would be essential to making it commercially feasible. That type of management is possible and has been achieved on certain exemplary farms (Hinman, 2006). Although COW had high weed interference, just two thorough hand-weeding events were sufficient to maintain onion yields.

This experiment found that foxtail millet is not a desirable cover crop for this system of no-till overwintered vegetable production. It appears that ground coverage and thickness of the grass residue negatively affected onion plant stand and overall yield. Millet in a mixture with cowpea either reduced onion yield or had comparable yield to cowpea as a monocrop. Although MIL did reduce weed interference in 2006-2007 compared with COW, there was no significant difference in 2007 2008. In addition, foxtail millet appears to be 

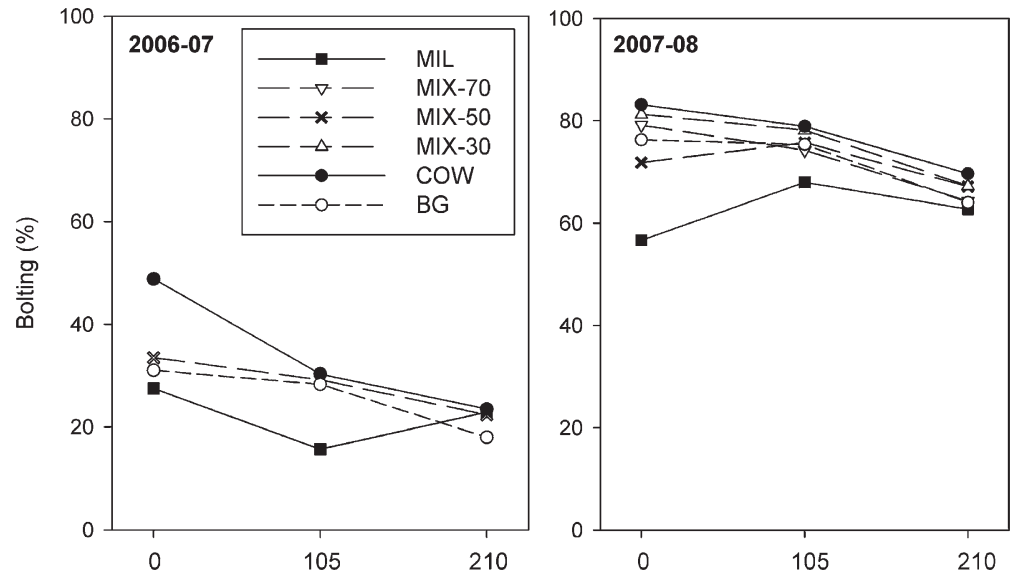

Fig. 5. Bolting frequency as affected by cover crop treatments across nitrogen $(\mathrm{N})$ rates 0,105 , and $210 \mathrm{~kg} \mathrm{~N} /$ ha of soybean meal in 2006-2007 and 2007-2008. MIL = millet; MIX-70, MIX-50, MIX-30 = cowpea with high, middle, and low seeding rates of millet, respectively; $\mathrm{COW}=$ cowpea; $\mathrm{BG}=$ bare ground.

a poor choice for a midsummer-seeded cover crop in eastern North Carolina as a result of its susceptibility to foliar disease.

Soybean meal shows potential as an effective source of $\mathrm{N}$ even when surfaceapplied in cool weather months. The $105 \mathrm{~kg}$ $\mathrm{N} / \mathrm{ha}$ rate could potentially serve as a starter fertilizer with a subsequent application in the spring, which could reduce $\mathrm{N}$ loss through leaching from the $210 \mathrm{~kg} \mathrm{~N} /$ ha rate applied all at once. Because the peak soil mineral $\mathrm{N}$ on fertilized plots did not correspond with onion uptake, split applications of soybean meal could be an important improvement on the one application management scheme used in this experiment (Sullivan et al., 2001). This study showed that $\mathrm{N}$ would be available for plant uptake in less than 2 weeks after surface-applying soybean meal, which facilitates the use of soybean meal in multiple applications tailored to timing of crop plant demand.

\section{Literature Cited}

Abdul-Baki, A.A., R.D. Morse, T.E. Devine, and J.R. Teasdale. 1997a. Broccoli production in forage soybean and foxtail millet cover crop mulches. HortScience 32:836-839.

Abdul-Baki, A.A., R.D. Morse, J.R. Teasdale, and T.E. Devine. 1997b. Nitrogen requirements of broccoli in cover crop mulches and clean cultivation. Journal of Vegetable Crop Production. 3:85-100.

Ashford, D.L. and D.W. Reeves. 2003. Use of a mechanical roller-crimper as an alternative kill method for cover crops. Amer. J. Altern. Agr. 18:37-45.

Bowman, G., C. Shirley, and C. Cramer. 1998. Managing cover crops profitably, p. 95-99. 2nd Ed. Sustainable Agriculture Network, Beltsville, MD.

Boyhan, G.E., A.C. Purvis, W.M. Randle, R.L. Torrance, M.J.I.V. Jefferson Cook, G. Hardison, R.H. Blackley, H. Paradice, C.R. Hill, and J.T. Paulk. 2005. Harvest and postharvest quality in short-day onions in variety trials in Georgia, 2000-03. HortTechnology 15:694-706.
Brewster, J.L. 2008. Physiology and environmental control of flowering, p. 138-148. Onions and other vegetable alliums.. 2nd Ed. CAB International, Wallingford, UK.

Chellemi, D.O. and E.N. Rosskopf. 2004. Yield potential and soil quality under alternative crop production practices for fresh market pepper. Renewable Agriculture and Food Systems. 19:168-175.

Cherr, C.M., R. McSorley, and J.M.S. Scholberg. 2006a. Green manure approaches to crop production: A synthesis. Agron. J. 98:302-319.

Cherr, C.M., J.M.S. Scholberg, and R. McSorley. 2006b. Green manure as nitrogen source for sweet corn in a warm-temperate environment. Agron. J. 98:1173-1180.

Creamer, N.G. and K.R. Baldwin. 2000. An evaluation of summer cover crops for use in vegetable production systems in North Carolina. HortScience 35:600-603.

Creamer, N.G., M.A. Bennett, B.R. Stinner, and J. Cardina. 1996a. A comparison of four processing tomato production systems differing in cover crop and chemical inputs. J. Amer. Soc. Hort. Sci. 121:559-568.

Creamer, N.G., M.A. Bennett, B.R. Stinner, J. Cardina, and E.E. Regnier. 1996b. Mechanisms of weed suppression in cover crop-based production systems. HortScience 31:410-413.

Creamer, N.G. and S.M. Dabney. 2002. Killing cover crops mechanically: Review of recent literature and assessment of new research results. Amer. J. Altern. Agr. 17:32-40.

Díaz-Pérez, J.C., A.C. Purvis, and J.T. Paulk. 2003. Bolting, yield, and bulb decay of sweet onion as affected by nitrogen fertilization. J. Amer. Soc. Hort. Sci. 128:144-149.

Díaz-Pérez, J.C., W.M. Randle, G. Boyhan, R.W. Walcott, D. Giddings, D. Bertrand, H.F. Sanders, and R.D. Gitaitis. 2004. Effects of mulch and irrigation system on sweet onion. I. Bolting, plant growth, and bulb yield and quality. J. Amer. Soc. Hort. Sci. 129:218 224.

Díaz-Pérez, J.C., J. Silvoy, S.C. Phatak, J. Ruberson, and R. Morse. 2008. Effect of winter cover crops and no-till on the yield of organically-grown bell pepper (Capsicum annuum L.). Acta Hort. 767:243-247.

Downer, J., B. Faber, and J. Menge. 2002. Factors affecting root rot control in mulched avocado orchards. HortTechnology 12:601-605.
Gaskell, M. and R. Smith. 2007. Nitrogen sources for organic vegetable crops. HortTechnology $17: 431-441$.

Herrero, E.V., J.P. Mitchell, W.T. Lanini, S.R. Temple, E.M. Miyao, R.D. Morse, and E. Campiglia. 2001. Use of cover crop mulches in a no-till furrow-irrigated processing tomato production system. HortTechnology 11:43-48.

Hinman, T. 2006. A whole farm approach to managing weeds in onions: Eric and Anne Nordell's Beech Grove Farm, Pennsylvania. ATTRAnews. National Sustainable Agriculture Information Service. 12 Nov. 2008. <http://attra. ncat.org/attra-digest/ATTRAnews_Sept-Oct06. pdf $>$.

Hutchinson, C.M. and M.E. McGiffen Jr. 2000. Cowpea cover crop mulch for weed control in desert pepper production. HortScience 35:196198.

Lu, Y.C., K.B. Watkins, J.R. Teasdale, and A.A. Abdul-Baki. 2000. Cover crops in sustainable food production. Food Rev. Intl. 16:121-157.

Müller, T. and P. von Fragstein und Niemsdorff. 2006. Organic fertilizers derived from plant materials. Part II: Turnover in field trials. J. Plant Nutr. Soil Sci. 169:265-273.

National Climatic Data Center. 2007. Climate of 2007-September U.S. Drought Watch. 23 Sept. 2008. <http://www.ncdc.noaa.gov/oa/ climate/research/2007/sep/us-drought.html>.

Oelke, E.A., E.S. Oplinger, D.H. Putnam, B.R. Durgan, J.D. Doll, and D.J. Undersander. 1990. Millets. Alternative field crops manual. University of Wisconsin-Extension, Cooperative Extension; University of Minnesota: Center for Alternative Plants \& Animal Products and the Minnesota Extension Service. 12 Nov. 2008. $<$ http://www.hort.purdue.edu/newcrop/afcm/ millet.html $>$.

Peigné, J., B.C. Ball, J. Roger-Estrade, and C. David. 2007. Is conservation tillage suitable for organic farming? A review. Soil Use Manage. 23:129-144.

Perry, K.B. 1996. Average first fall frost dates for selected North Carolina locations. Horticulture information leaflets. North Carolina Cooperative Extension Service. 15 Sept. 2008. <http://www. ces.ncsu.edu/depts/hort/hil/hil-708.html>.

Ranells, N.N. and M.G. Wagger. 1997a. Grasslegume bicultures as winter annual cover crops. Agron. J. 89:659-665.

Ranells, N.N. and M.G. Wagger. 1997b. Nitrogen release from grass and legume cover crop monocultures and bicultures. Agron. J. 88:777-782.

Sainju, U.M., W.F. Whitehead, and B.P. Singh. 2005. Biculture legume-cereal cover crops for enhanced biomass yield and carbon and nitrogen. Agron. J. 97:1403-1412.

Sanders, D.C. (ed.). 2004. Vegetable crop guidelines for the southeastern U.S. 2004-2005. North Carolina Vegetable Growers Association, Raleigh, NC.

Sargent, S.A., P.J. Stoffella, and D.N. Maynard. 2001. Harvest date affects yield and postharvest quality of nondried, short-day onions. HortScience 36:112-115.

Stadler, C., R. Gutser, H. Heuwinkel, S. von Tucher, and U. Schmidhalter. 2006. Nitrogen release from plant-derived and industrially processed organic fertilizers used in organic horticulture. J. Plant Nutr. Soil Sci. 169:549 556.

Stirzaker, R.J., B.G. Sutton, and N. Collis-George. 1993. Soil management for irrigated vegetable production. I. The growth of processing tomatoes following soil preparation by cultivation, zero-tillage and an in situ-grown mulch. Aust. J. Agr. Res. 44:817-829. 
Sullivan, D.M., B.D. Brown, C.C. Shock, D.A. Horneck, R.G. Stevens, G.Q. Pelter, and E.B.G. Feibert. 2001. Nutrient management for onions in the Pacific Northwest. Pacific Northwest Extension. 6 Aug. 2006. <http:// extension.oregonstate.edu/catalog/html/pnw/ pnw546/>.

Teasdale, J.R. and A.A. Abdul-Baki. 1998. Comparison of mixtures vs. monocultures of cover crops for fresh-market tomato production with and without herbicide. HortScience 33:1163-1166.
Teasdale, J.R. and C.L. Mohler. 2000. The quantitative relationship between weed emergence and the physical properties of mulches. Weed Sci. 48:385-392.

Tonitto, C., M.B. David, and L.E. Drinkwater 2006. Replacing bare fallows with cover crops in fertilizer-intensive cropping systems: A meta-analysis of crop yield and $\mathrm{N}$ dynamics. Agr. Ecosyst. Environ. 112:58-72.

Treadwell, D.D., N.G. Creamer, G.D. Hoyt, and J.R. Schultheis. 2008. Nutrient management with cover crops and compost affects development and yield in organically managed sweetpotato systems. HortScience 43:1423-1433.

USDA. 1995. United States standards for grades of Bermuda-Granex-Grano type onions. USDA Agricultural Marketing Service, Washington DC.

Wang, G., M. Ngouajio, M.E. McGiffen, Jr., and C.M. Hutchinson. 2008. Summer cover crop and in-season management system affect growth and yield of lettuce and cantaloupe. HortScience 43:1398-1403. 